\title{
Covid-19: Concerns rise as cases expand rapidly in South America
}

\author{
Rodrigo de Oliveira Andrade
}

São Paulo

Scientists have warned that countries in South America should expect a rise in cases and deaths from covid-19 in the next month as the pandemic on the continent is about six weeks behind that in Europe in terms of transmission of the virus and infection rate. To date around 320000 cases and almost 17000 deaths have been reported in the region.

On 12 May the Pan American Health Organization said that between 4 and 11 May more than 96000 additional cases and 5552 deaths were reported in South America, a 45\% relative increase in cases and a $51 \%$ relative increase in deaths when compared with the previous week.

PAHO's director, Carissa Etienne, said that health systems in large cities such as Lima and Rio de Janeiro were quickly becoming overwhelmed by covid-19. But the pandemic also affected "smaller towns and remote communities, including indigenous areas, where access to healthcare is challenging," she said.

Etienne called on countries to tackle their health, social, and economic emergencies, saying that she was "deeply concerned" by the rapid expansion of the covid- 19 pandemic in the Americas. She called on "national and local health authorities to work even more closely together to contain the spread of the virus and support health system capacity."

The situation was particularly worrisome in Brazil, the hardest hit nation, which has recorded about 170000 cases and more than 12000 deaths, although these numbers are thought to be a gross underestimate.

Pedro Hallal, an epidemiologist at the Federal University of Pelotas, in Rio Grande do Sul, told The BMJ, "Brazil has insufficient access to testing, meaning there must be a huge number of unreported cases."

A study by researchers at Imperial College London found that Brazil was the country with the highest rate of transmission among 48 nations analysed worldwide. ${ }^{1}$

The government has handed responsibility for social isolation measures to local authorities, and some cities such as São Luis, capital of the poor northeastern state of Maranhão, announced a complete lockdown to contain coronavirus spreading on 5 May. $^{2}$

However, Brazil's president, Jair Bolsonaro, continues to downplay the dangers of covid-19 by discouraging social distancing and urging the population to get back to work. ${ }^{34}$
In Ecuador, which has registered 29509 infections and 2145 deaths as at 12 May, the situation is especially critical in the city of Guayaquil, where an estimated third of the 2.7 million residents are infected with covid-19. ${ }^{5}$

The country faces the collapse of its health and funeral systems, with reports of bodies left on pavements, packed into cardboard coffins, and stacked in morgues. "Although its population is considerably smaller, the incidence of covid-19 in Ecuador is more than twice that observed in Brazil," Hallal said. Against this background President Lenin Moreno has said that the country has stabilised the numbers of new cases and announced a plan to restart the economy. ${ }^{7}$

In Peru, which has the second highest number of cases in the region after Brazil, the government extended the national lockdown to 24 May, as the number of new cases reached nearly 70 000, with almost 2000 deaths confirmed.

Authorities in Chile had acted swiftly against the pandemic, said Claudio Méndez, an associate professor of health policy at the Austral University of Chile, in Valdivia. "The government hastened to prepare the country by allowing health services to hire health workers and buy supplies as the World Health Organization declared the disease a public health emergency," he told The BMJ.

He explained that Chile was relying on a system of selective quarantine in areas where infections were high, rather than imposing social isolation throughout the whole territory. The strategy seems to be effective so far. In a population of 18.7 million people, Chile has registered 30063 cases and 323 deaths as at 12 May.

Paraguay also acted quickly to control the pandemic by announcing a rigorous lockdown on 10 March before any neighbouring countries. It has so far kept the number of cases and deaths below 1000 .

However, as in other South American countries, many people in Paraguay are going hungry in their own homes because some two thirds of the country's working population cannot access the benefits announced by the government to help tackle the pandemic. ${ }^{8}$

In Argentina, which introduced lockdown on 20 March and has recorded 6265 cases of covid-19 and 314 deaths as at 12 May, the government announced on 8 May that it would loosen social distancing measures in the regions without new transmissions.

However, Etienne said in the press briefing on 12 May that "only when countries have controlled transmission will they be 
in a position to implement a well planned, cautious transition period."

She added, "Covid-19 reminds us that when we invest in health systems we keep our people safe and our economies strong. When we guarantee access to health services for everyone, we reduce inequality and build more resilient societies."

1 Bhatia S, Cori A, Parag KV, et al. Short-term forecasts of COVID-19 deaths in multiple countries. Imperial College London. 2020. https://mrc-ide.github.io/covid19-short-termforecasts/index.html.

2 Paraguassu L. First major city in Brazil declares lockdown as virus spreads. Reuters. 2020. https://www.reuters.com/article/health-coronavirus-brazil-lockdown/first-major-cityin-brazil-declares-lockdown-as-virus-spreads-idUSL1N2CN1KV.

3 de Oliveira Andrade R. The Brazilian slums hiring their own doctors to fight covid-19. BMJ 2020;369:m1597. 10.1136/bmj.m1597 32321703
$4 \quad$ Phillips T. Bolsonaro ignored by state governors amid anger at handling of Covid-19 crisis. Guardian. 2020. https:/wwwtheguardian.com/world/2020/apr/01/brazil-bolsonaro-ignoredby-state-governors-amid-anger-at-handling-of-covid-19-crisis.

5 Um terço dos 2,7 milhões de moradores de Guayaquil, no Equador, contraiu a Covid-19. 2020. https://g1.globo.com/mundo/noticia/2020/05/08/um-terco-dos-27-milhoes-demoradores-de-guayaquil-no-equador-contraiu-a-covid-19.ghtml.

6 Cabrera JML, Kurmanaev A. Ecuador's death toll during outbreak is among the worst in the world. New York Times. 2020. https://www.nytimes.com/2020/04/23/world/americas/ ecuador-deaths-coronavirus.html.

7 Ecuador has stabilized number of new coronavirus cases: president. 2020. New York Times. https://www.nytimes.com/reuters/2020/04/30/world/americas/30reuters-healthcoronavirus-ecuador.html.

8 Costa W. Paraguayans go hungry as coronavirus lockdown ravages livelihoods. Guardian 2020. https://www.theguardian.com/global-development/2020/apr/12/paraguay-coronavirushungry-social-inequalities.

Published by the BMJ Publishing Group Limited. For permission to use (where not already granted under a licence) please go to http://group.bmj.com/group/rights-licensing/ permissions 